\title{
Status of Treaty under the Constitution of SAARC Countries: An Approach towards Bangladesh and India Perspective
}

\author{
M. Z. Ashraful \\ South Asian University, New Delhi \\ m.ashraful92@yahoo.in
}

Doi:10.5901/mjss.2014.v5n2p129

\section{Abstract}

This paper has tried to find out the status of treaty under the Constitution of respective countries of SAARC Nations and also explicated the relevant provisions enshrined in the Constitutions. An attempt has been taken by this paper to describe the position of international treaties which are entered into by the SAARC countries in the municipal legal system as compared to international law in the South Asian region. Basically, this paper has discussed the position of South Asian Countries and the role of other organs of the state such as Parliament, Judiciary regarding the status of treaty.

\section{Initial Remarks}

At present in South Asia, all the eight countries have written constitution and they are practicing democratic system. They are participating and performing crucial role in the international geo- political arena. All these countries are sovereign and civilized nations in the world and hence they are the subject of international law as like other sovereign state. SAARC countries are regularly entering into international treaty, convention, and covenant or protocol etc whether it may be bilateral treaty or multi -lateral. They have also ratified and entered into so many conventions relating to Human Rights. So there is a bundle of questing always arise that what is the status of those treaties in the domestic legal system of these SAARC countries or what are the provisions enshrined in the constitution regarding the status of international treaty or convention or are all these treaties treated equally in the domestic legal system in this region or how do domestic court treat these treaty. I have attempted to identify the status of treaty under the constitution of SAARC countries and I have taken two countries as such Bangladesh and India for detail explanation of some extent.

\section{Provisions Regarding the Status of International Treaty under the Constitution of SAARC Countries}

Almost all the constitution of SAARC countries has adopted some provisions regarding the status of treaty, ratification of treaty or adoption of treaty. The kingdom of Bhutan is a newly emerging democratic country. The form of government shall be that of a democratic constitutional monarchy. ${ }^{1}$ The constitution of the Kingdom of Bhutan provides that except for existing International Conventions, Covenants, Treaties, Protocols, and Agreements entered into by Bhutan, which shall continue in force subject to section 10 of article 1, all International Conventions, Covenants, Treaties, Protocols and Agreements duly acceded to by the Government hereafter, shall be deemed to be the law of the Kingdom only upon ratification by Parliament unless it is inconsistence with this Constitution. ${ }^{2}$ Before entering into constitutional monarchy all conventions, treaties, protocols and agreement shall remain in force subject to the section 10 of Article 1 of the Constitution of the Kingdom of Bhutan. According to the Section 10 of article 1, all laws in force in the territory of Bhutan at the time of adopting this constitution shall continue until altered, repealed or amended by parliament. The provisions of any law, whatever made before or after the coming into force of this constitution, which are inconsistent with this constitution shall be null and void. However, under the constitution, parliament has empowered to ratify any treaty or conventions with a view to implementation as a law in the domestic level. Without ratification by parliament there is no legal status in the domestic legal system. There is also one provision regarding the ratification of treaty in the constitution of Maldives. Article 93 of the Constitution of the Republic of Maldives, 2008 provides that

a) Treaties entered into by the Executive in the name of the State with foreign states and international organizations shall be approved by the People's Majlis, and shall come into force only in accordance with the

1. Article 1(2), The Constitution of the Kingdom of Bhutan.

2. Article 10(25), Ibid. 
decision of the People's Majlis.

b) Despite the provisions of article (a), citizens shall only be required to act in compliance with treaties ratified by the State as provided for in a law enacted by the People's Majlis.

Sri Lanka has ratified the following relevant international human rights and humanitarian law treaties:

a) Genocide Convention (12 October 1950)

b) Geneva Conventions 1949 (28 February 1959)

c) ICCPR (11 September 1980)

d) ICESCR (11 September 1980)

e) CEDAW (5 October 1981)

f) CERD (18 February 1982)

g) CRC (12 July 1991)

h) Convention against Torture (3 January 1994)

i) Optional Protocol ICCPR (31 November 1997)

Customary international law and human rights treaties ratified by Sri Lanka have no status in national law. They cannot be directly invoked or enforced through the courts or by the administration in Sri Lanka. They must be transformed into domestic law before the courts or competent authorities can apply them. Even so, the Courts of Sri Lanka have referred to them in their judgements. Sri Lanka has enacted the Convention against Torture and other Cruel, Inhuman or Degrading Treatment or Punishment Act No. 22 of 1994 to give effect to the Torture Convention. ${ }^{3}$ Under the constitution of Sri Lanka where Parliament by resolution passed by not less than two-thirds of the whole number of Members of Parliament (including those not present) voting in its favour, approves as being essential for the development of the national economy, any Treaty or Agreement between the Government of Sri Lanka and the Government of any foreign State for the promotion and protection of the investments in Sri Lanka of such foreign State, its nationals, or of corporations, companies and other associations incorporated or constituted under its laws, such Treaty or Agreement shall have the force of law in Sri Lanka and otherwise than in the interests of national security no written law shall be enacted or made, and no executive or administrative action shall be taken, in contravention of the provisions of such Treaty or Agreement. ${ }^{4}$ Article 156 of the interim Constitution of Nepal provides the provisions relating to the ratification of, accession to acceptance of or approval of treaty or agreement. According to this article -

1) The ratification of , accession to, acceptance of or approval of treaties or agreements to which the State of Nepal or the Government of Nepal is to become a party shall be as determined by the law.

2) The laws to be made pursuant to clause (1) shall, inter alia, require that the ratification of, accession to, acceptance of or approval of treaty or agreements on the following subjects be done by a two-thirds majority of the total number of members of the Legislature-Parliament present in the House:-

(a) peace and friendship;

(b) security and strategic alliance;

(c) the boundaries of Nepal; and

(d) natural resources and the distribution of their uses.

Provided that out of the treaties and agreements referred in the sub clauses (a) and (d), if any treaty or agreement is of ordinary nature and which does not affect the nation extensively, seriously or in the long-term, the ratification of, accession to, acceptance of or approval of such treaty or agreement may be done at a meeting of the Legislature-Parliament by a simple majority of the members present in the House.

3) After the commencement of the Constitution, unless a treaty or agreement is ratified, acceded, accepted or approved in accordance with this Article, it shall not be binding to the Government of Nepal or the State of Nepal.

4) Notwithstanding anything written in clauses (1) and (2), no treaty or agreement shall be concluded that may have detrimental effect on the territorial integrity of Nepal.

In Nepal there is a treaty Act named The Nepal Treaty Act, 1990 is existed. According to the Treaty Act no one, except, the Prime minister and the Minister of Foreign Affairs, shall negotiate, accept the final draft or a certified copy, or sign or maintain reservations, or perform any other function related to a treaty to which Nepal or Government of Nepal is a party, without full power. Provided that nothing contained in this Section shall prejudice the power of a Nepalese Ambassador of Charge d'Affaires representing Nepal in any foreign nation or international organization to conclude a

3.Country Report of Srilnaka, Redress, London, Available at: http://www.redress.org/downloads/country-reports/SriLanka.pdf Date of Accession on 7 November, 2013.

4. Article 157, The Constitution of the Democratic Socialist Republic of Sri Lanka. (As amended up to 03rd Octuber, 2001) 
treaty on any matter with such foreign nation or inter-governmental organization, as well as the leader of a delegation participating in any international conference to negotiate or accept the final draft or a certified copy of the treaty to be signed in the conference. ${ }^{5}$ In case of Afghanistan, the Constitution of the Islamic Republic of Afghanistan provides that the state shall observe the United Nations Charter, inter-state agreements, as well as international treaties to which Afghanistan has joined, and the Universal Declaration of Human Rights. ${ }^{6}$ In Afghanistan, the National Assembly has empowered to ratification of international treaties and agreements, or abrogation of membership of Afghanistan in them. ${ }^{7}$ In Pakistan there is no clear provision regarding the status of international treaty, ratification of treaty or foreign affairs at all.

\section{An Approach towards Bangladesh and India Perspective}

As like other common law countries, Bangladesh follows dualistic approach as regards the ratification and incorporation of international treaty within the domestic law. The constitution of Bangladesh contains two main provisions regarding the international law; one of them Article 25 which refers to the promotion of international peace, security and solidarity in accordance with the basic principle of international law and another one is Article 145A which governs the adoption and codification of international treaties in domestic law. According to the constitution of Bangladesh "All treaties with foreign countries shall be submitted to the president, who shall cause them to be laid before parliament, provided that any such treaty connected with national security shall be laid in a secret session of parliament." 8 This provision of the constitution provides one kind of obligation to present treaty before the parliament only for discussion not for ratification. On the other hand if any treaty relates to the national security then it will be discussed by the secret session of parliament and what does the secret session mean it is not defined in the constitution of Bangladesh. It can be defined that a secret session is the secret settings of the house where no stranger shall be permitted to be present in the Chamber, Lobbies or Galleries of the parliament except the authorisation of speaker. ${ }^{9}$ There is another crucial debate is that in this situation the right to know of the peoples of the Republic has limited. If the government enters into a treaty blended with national security then there is no scope to know by the peoples which have discussed by parliament.

Treaty making power is an executive power rather than legislative. It is stated in the constitution of Bangladesh that the President shall, as Head of State, exercise and perform duties conferred and imposed on him by the constitution and by any other law..$^{10}$ The constitution also provides that all executive actions of the government shall be taken in the name of President. ${ }^{11}$ However, Bangladesh has a parliamentary form of government and the President is treated as a nominal head. So the executive powers are performed by prime minister and the cabinet. Hence the prime minister and cabinet determine the treaty making policies of Bangladesh ${ }^{12}$ although there is an obligation to lay a treaty before Parliament. But failure to lay a treaty before Parliament will not affect its validity. ${ }^{13}$ The parliament of Bangladesh has no power under the constitution to modify or repeal any treaty but can implement any treaty by enacting legislation regarding the particular treaty into domestic law.

Courts in Bangladesh cannot enforce treaties even if ratified by the state. They must be incorporated in the municipal legislation. ${ }^{14}$ However, the court does utilize international conventions and covenants as an aid to interpretation of the provisions of Part III of the constitution, particularly to determine the right to life and the right to liberty, but not to enumerate within the Constitution. In Kazi Mukhlesur Rahman vs. Bangladesh ${ }^{15}$ where the Court dismissed the application on the ground that it was not ripe for decision. In this regard Court can examine the treaty making power of the executive under the constitution. The executive power of the Prime Minister shall be exercised in accordance with the Constitution, which imposes limitations on its treaty-making power, particularly when boundary settlement is involved. The Constitution of Bangladesh provides that Parliament may from time to time by law provide for determination of

\footnotetext{
5. Section 3, The Nepal Treaty Act, 2047 (1990).

6. Article 7, The Constitution of the Islamic Republic of Afghanistan.

7. Article 90, Ibid.

8. Article 145A, The Constitution of the People's Republic of Bangladesh.

9. Article 181, The Rules of Procedure of Parliament of the People's Republic of Bangladesh as modified up to $11^{\text {th }}$ January, 2007.

10. Article 48(2); The Constitution of the People's Republic of Bangladesh.

11. Article 55(4), ibid.

12. The second Proclamation Order No. IV of 1978.

13. Major (Retd.) Akhtaruzzaman vs. Bangladesh, Writ Petition No. 3774 of 1999

14. Chaudhury and Kendra vs. Bangladesh, Writ Petition No. 7977 of 2008; 29 BLD (HCD), 2009; Bangladesh vs. Hasina, 60 DLR (AD), $2008,90$.

15. $26 \operatorname{DLR}(1974) 44$
} 
boundaries of the territory of Bangladesh and of the territorial waters and the continental shelf of Bangladesh. ${ }^{16}$ On the other hand it was held in the case of Ershad vs. Bangladesh and others ${ }^{17}$ that although universal human rights norms, whether given in the UDHR or in the Covenants, are not directly enforceable in national courts, they are enforceable by domestic courts if such norms are incorporated into the domestic law. Where there is a gap in the municipal law in addressing any issue, the courts may take recourse to international conventions and protocols on that issue for the purpose of formulating effectives and guidelines to be followed by all concerned until national legislation enacts laws in this regard. ${ }^{18}$ The court found that Bangladesh is a state party to the international Convention of the Rights of Child, 1989; the treaty is binding on Bangladesh. ${ }^{19}$ In another case the Court referred international instruments and on the basis of the jurisprudence from those instruments, it decided that the Government is responsible for ensuring a free and fair trial not only to the accused but also to the victim of a crime. In essence, the fair trial of the accused also implied that the victim must be able to give evidence without fear and insecurity. In support of this judgment, the court had recourse to the universal human rights norm of the right to life, liberty and security of a person. The court used the provision of article 3 of UDHR, Resolution 217 A (III); UN Doc A/810 91, UN general Assembly, to interpret Article 32 of the Constitution of Bangladesh. ${ }^{20}$ However the courts would not enforce international human rights treaties, even if ratified by Bangladesh, unless these were incorporated in municipal laws, but they would have looked into the ICCPR while interpreting the provisions of the constitution to determine the right to life, liberty and other rights. ${ }^{21}$

Although the Constitution of Bangladesh is the Supreme law of the land does not contain any express provision as to ratification or requiring any legislative approval of treaty. In some situation Court has tried to identify the status of treaty under the constitution and made some clarification which have discussed above. It is identified that the status of all treaties are not same particularly some human rights treaties and conventions. However, the status of treaty under the constitution within the domestic law still remains in many cases unclear. It can be concluded that except to the extent that a treaty becomes incorporated into the laws of Bangladesh by an Act of Parliament, the Courts have no power to enforce the treaty rights and obligations at the behest of sovereign government or at the behest of a private individual. ${ }^{22}$

On the other hand the Constitution of India does not contain precise provisions regarding to the status of treaty in its domestic legal system. The main provisions of the Constitution of India relevant to the treaty as well as International Law are;

(1) Article 51,

(2) Article 73,

(3) Article 245,

(4) Article 246,

(5) Article 253,

(6) Article 260,

(7) Article 363,

(8) Article 372, and

(9) VII schedule - entries 10 to 21

According to the Constitution of India the state shall endeavour to foster respect for International Law and Treaty obligations in the dealings of organized people with one another. ${ }^{23}$ Article 51 has been relied upon by Courts to hold that various International Covenants, Treaties etc., particularly those to which India is a party or signatory, become part of Domestic Law in so far as there is no conflict between the two. ${ }^{24}$ In "Unnikrishnan v. state of Andhra Pradesh" the Supreme Court of India has utilized Article 51(c), which merely required the State to foster respect for international law

\footnotetext{
16. Article 143(2) of the Constitution of People's Republic of Bangladesh.

17. Appeal, 21 BLD (AD), 2001, 69;

18. BNWLA vs. Government of Bangladesh, 31 BLD, (2011), HCD, at 324.

19. Zahida Ahmed (Liza) vs. Syed Noor Uddin Ahmed and another, Law Guardian, Vol. 7, HCD, 2010, at 168.

20. Tayazuddin and another vs. Bangladesh, Criminal Appeal, 21 BLD (HCD) 2001 at Para 26.

21. Bangladesh and another vs. Hasina and another, Appeal Judgment, No. 46/2008; 60 DLR (AD), 2008, 90; ILDC 1409 (BD) 2008,8 May 2008, at paragraph 86.

22. Islam, Mahmudul; Constitutional Law of Bangladesh, 3rd Ed. Published by Mullick Brothers (2012), at 1026.

23. Article 51 (c), The Constitution of India.

24. In Re Berubari Union and Exchange of Enclaves, AIR 1960 SC 845; Ali Akbar v. U.A.R. AIR 1966 SC 230; Magnabhai v. Union of India, AIR 1969 SC 783; Gramaphone Co. Birendra, AIR 1984 SC 667; Jolly George Verghese V. Bank of Cochin, AIR 1980 SC 470; UPSE Board v. Hari Shankar, AIR 1979 SC 65; Prem Shankar Shukla v. Delhi Adm., AIR 1980 SC 1535; Vishaka v. State of Rajasthan, AIR 1997 SC 3011. Legal India, Legal Service Network and Free Law Resource Portal available at: http://www.legalindia.in/the-status-of-international-law-under-the-constitution-of-india Date of Accession on 10 November,2013.
} 
and treaty obligations, for the purpose of protecting human rights and bringing about a social order which did away with inequality and extended justice to the extent of the powers of the Supreme Court. ${ }^{25}$ The executive power of the Union extends to the exercise of such rights, authority and jurisdiction as are exercisable by the government of India by virtue of any treaty or agreement. ${ }^{26}$ It is important to mention here that the President is empowered to enter into any treaty or convention because the executive power of the Union vests with the President of India. ${ }^{27}$ But the president shall act subject to aid and advice of the Council of Ministers with the Prime Minister at the head. ${ }^{28}$ So, treaty making power in India is an executive act.

Article 253 gives the power to enact laws implementing treaties, conventions etc to the parliament. According to the Article, parliament has power to make any law for the whole or any part of the territory of India for implementing treaty, agreement or convention with any other country or countries or any decision made any international conference, association or other body. However, it is important to mention here that all treaties are non-self-executing and hence domestic legislation is required to execute any treaty.

There is no doubt that the Union Government has got unlimited treaty-making power under Article 253, read with Entries 13 and 14 of List I, Schedule VII. ${ }^{29}$ As to the position of treaties in Indian law, two views exist. ${ }^{30}$ These are:

a) The traditional view held by Basu on one hand who advances the view that no treaties which have not been implemented by legislation are binding on the municipal courts, relying on Article 253 of the Constitution.

b) On the other hand Alexandrowicz contends that not all treaties must be implemented by legislation. He cites several cases as authority for assuming that certain treaties only, such as treaties affecting private rights, must be enacted by legislation to become enforceable.

Under Article 246 of the Constitution (read with Entry 14 of List I of the Seventh Schedule), Parliament has power to enact a law regulating treaty-making power but it has not yet exercised that power. The Constitution Bench of Supreme Court of India observed that; "The effect of Art 253 is that if a treaty, agreement or convention with a foreign state deals with a subject within the competence of state legislature, the parliament alone has notwithstanding Article 246(3) the power to make laws to implement the treaty, agreement or convention or any decision made at any international conference, association or other body." 31 A virtual judicial incorporation of treaty law into the "corpus juris" has been the Supreme Court decisions in "Vishaka v. State of Rajasthan" wherein the court held that international conventions and norms were to be read into fundamental rights in the absence of enacted domestic law occupying the field. ${ }^{32}$ Treaties which are part of the international law do not form part of the law of the land unless expressly made so by the legislative authority. ${ }^{33}$ According to the Article 260 of the Constitution of India the Government of India may by agreement with the Government of any territory not being part of the territory of India undertake any executive, legislative or judicial functions vested in the government of such territory, but every such agreement shall be subject to, and governed by, any law relating to the exercise of foreign jurisdiction for the time being in force. On the other hand Article 263 of the Constitution provides that "Notwithstanding anything in this constitution but subject to the provisions of Article 143 , neither the Supreme Court nor any other court shall have jurisdiction in any dispute arising out of any provision of treaty, agreement, covenant, engagement, sanad or other similar instrument which was entered into or executed before the commencement of this constitution by any ruler of an Indian State and to which the Government of the Dominion of India or any of its predecessor Governments was a party and which has or has been continued in operation after such commencement, or in any dispute in respect of any right accruing under or any liability or obligation arising out of any of the provisions of this constitution relating to any such treaty, agreement covenant, engagement, sanad or other similar instrument...........". It was held by the Supreme Court of India exercising advisory jurisdiction under Article 143 of the constitution that in case of implementation of treaty related with the exchange Indian Territory there must be needed a

25. Kadoliya, Narendra; A Paradigm Shift In The Role Of Domestic Courts In Implementing International Treaty Provisions: An Indian Perspective; available at: http://www.manupatrafast.com/articles/PopOpenArticle.aspx?ID=33629224-6c04-4eb5-97bd-56dafd3b2eb4 \&txtsearch=Subject:\%20Miscellaneous Date of Accession on 12 November, 2013.

26. Article 73 (b); The Constitution of India.

27. Article 53; ibid.

${ }^{28}$. Article 74; ibid.

29. Ullah, Wali; The Treaty - Making under the Constitution of India, Web Journal, available at: http://www.ebc-india.com/lawyer/articles/

71v2a5.htm, Date of Accession on 8 November, 2013

30. Supra Note 25.

31. Magnabhai Ishwarbhai Patel v. Union of India; AIR 1969 SC 783 at para 25.

32. Supra Note. 25

33. Birma v. State; AIR 1951, Raj 127. 
constitutional amendment and mere passing legislation is no sufficient. ${ }^{34}$

\section{Concluding Remarks}

All the SAARC countries have followed the dualistic mode in case of the ratification or adoption of treaty as like other common law tradition countries. Under the constitution of SAARC countries, the treaty making process is an executive act and no treaty shall be applicable in the domestic legal system unless and until the parliament of respective countries adopted it by enactment or ratified by requisite vote. The treaties are not supreme law of the land as like as USA where the treaties are the supreme law of the land. ${ }^{35}$ Though the status of international treaty is same in the South Asian Country but in case of ratification there are some variations. As for example, the power of ratification of international treaty or agreement lies to the National Assembly under the constitution of Afghanistan on the other hand in Bangladesh although there is a provision to lay before parliament which is not for ratification but for merely discussion. In Nepal there is a treaty Act relating to the ratification, accession or adoption of international treaty or agreement beside the constitutional provision which is the exception of SAARC Countries because none of the SAARC countries have treaty Act or legislation as like Nepal and India is an exception where the constitution has adopted more provision than other SAARC Countries' Constitution. While the status of all the treaties are same in the domestic level, the court of these respective countries are giving special emphasis on the Human Rights treaties in case of explanation of fundamental rights enshrined in the constitutions. So it is required to make legislations regarding the international treaty for more clarification of the status and position of treaties in the South Asian region and by formulating these it would be possible to develop a South Asian Approach as regards the status of treaty at the side of the common law practice.

\section{References}

The Constitution of People's Republic of Bangladesh;

The Constitution of India;

The Constitution of the Kingdom of Bhutan;

The Constitution of Democratic Socialist Republic of Sri Lanka;

The Interim Constitution of Nepal

The Constitution of the Islamic Republic of Afghanistan;

The Constitution of the Islamic Republic of Pakistan;

The Constitution of the Republic of Maldives;

The Constitution of the United State of America;

The Nepal Treaty Act, 1990;

The Rules of Procedure of Parliament of the People's Republic of Bangladesh as modified up to 11 th January, 2007;

The second Proclamation Order No. IV of 1978 of Bangladesh;

Dhaka Law Reports, Bangladesh Legal Decisions, All India Reports, Law Guardian Vol. 7;

Islam, Mahmudul; Constitutional Law of Bangladesh, 3rd Ed. Published by Mullick Brothers (2012);

Country Report of Srilnaka, Redress, London, Available at: http://www.redress.org/downloads/country-reports/SriLanka.pdf Date of Accession on 7 November, 2013.

Legal India, Legal Service Network and Free Law Resource Portal available at: http://www.legalindia.in/the-status-of-international-lawunder-the-constitution-of-india Date of Accession on 10 November,2013.

Ullah, Wali; The Treaty - Making under the Constitution of India, Web Journal, available at: http://www.ebcindia.com/lawyer/articles/71v2a5.htm, Date of Accession on 8 November, 2013

Kadoliya, Narendra; A Paradigm Shift In The Role Of Domestic Courts In Implementing International Treaty Provisions: An Indian Perspective; available at: http://www.manupatrafast.com/articles/PopOpenArticle.aspx?ID=33629224-6c04-4eb5-97bd56dafd3b2eb4\&txtsearch=Subject:\%20Miscellaneous Date of Accession on 12 November, 2013

34. Re Berubari Union and Exchange of Enclaves, AIR 1960 SC 845.

35. Article vi, Section 2, The Constitution of the United State of America. 